\title{
INCLUDING TRANSCULTURAL NURSING CONTENT IN THE CURRICULUM - PART 2
}

\section{$L$ de Villiers and $D$ van der Wal}

\section{ABSTRACT}

Transcultural nursing should be included in the curricula of the basic nursing courses. In this article, the transcultural nursing curriculum content that could be included, is discussed. To ensure a comprehensive approach to this field, a basic course in socio-cultural anthropology should be followed by transcultural nursing study units at strategic points in the curriculum.

\section{OPSOMMING}

Hierdie arrikel handel oor die inslutting van transkulturele verpleegkunde by die kurrikulum. Daar word slegs gefokus op die feirelike vakinhoud. Om 'n omvantende benadering te verseker, behoort 'n basiese kursus in sosiokulturele antropologie opgevolg te word met transkulturele verpleegkunde eenhede wat op strategiese punte van die kurrikulum ingesluit word.

\section{- INTRODUCTION}

As discussed in Part 1 of this study, a clear understanding of the connections between culture and health is necessary for the student nurse in South Africa to deliver appropriate transcultural nursing care

Transcultural nursing content may be divided into:-

- Basic anthropological knowledge

- The relationship between culture and health from both an anthropological and a transcultural nursing perspective.

- Self-knowledge.

- Cultural issues.

The following discussion is structured according to the above framework.

\section{BASIC ANTHROPOLOGICAL KNOWLEDGE}

Anthropology is the science of man Sociocultural anthropology is concerned with man within the context of society and culture (Translated from SKA 100.V, Enigste studiegids 1991:10 \& 12-13).

Basic sociocultural anthropology knowledge serves as a foundation for transcultural nursing content and such a course therefore should be included in the first year curriculum: desirable content would result in an understanding of cultural principles by the student. Simply learning lists of different cultural characteristics could lead to stereotyping of patients (Dobson 1983:53). Leininger (1991:49) identifies seven cultural and social structure dimensions namely, cultural valuesiway of living, technological, religiouslphilosophical, kinshiplsocial, politicallegal, economic and educational factors. These dimensions are culturally universal, but also culturally diverse (SKA 100.V, Enigste studiegids 1991:14). For instance, kinship is present in all cultures, but the nature of kinship differs considerably, especially between western and non-western cultures.

The meaning of culture, worldview and the cultural and social structure dimensions, should be studied to enhance understanding of the world of the patient as well as care expressions, pattems and practices. Concepts such as enculturation, ethnocentrism and cultural tolerance. could be included in this module

\section{THE RELATIONSHIP BETWEEN CULTURE AND HEALTH}

This concept is studied from an anthropological and a transcultural nursing perspective.

\section{THE ANTHROPOLOGICAL PERSPECTIVE}

This subject matter is divided into cultural factors that influence health, perception of health and disease within the cultural context, and sickness behaviour. It can form part of the basic sociocultural anthropology module.

\section{Cultural factors that influence health}

The issues that should be dealt with, are:

- Behavioural patterns such as smoking, eating and drinking habits, hygienic practices and traditional occupations (Akinsola 1983:18-20). Pervan, Bryce and Werner (1989:17) describe the role of smoking habits and the intake of-home-brewed beer with regard to the high incidence of carcinoma of the oesophagus in the former Transkei and Ciskei.

- Living conditions for instance, poverty and geographic factors (Akinsola 1983:26) Pervan, Bryce And Werner (1989:17) relate a high incidence of carcinoma of the oesophagus in the former Transkei and Ciskei to soil deficiencies and low rainfall in these regions.

- Culturally prescribed health promotive practices for example, methods of preparing food (Akinsola 1983:26).

- Biological characteristics as etiological factors for example, genetic predisposition to develop hypertension, hyperlypemia or carcinoma of the cervix (Leininger 1978:453).

\section{Perceptions regarding health and disease}

Such perceptions are culturally learned, as they are derived from the world view, and the seven cultural and social structure dimensions.

Health

Health is viewed from a magic-religious, biomedical or holistic perspective. From the magic-religious perspective, health, which is a gift from God or a god, is a community matter

According to the biomedical perspective, health is defined by means of physical and chemical bodily processes. The holistic perspective relates heal th to harmony between man and nature (Herberg 1989:26-35). 


\section{Sickness classification}

Sickness is a culturally universal feeling of being ill and can subsequently be explained according to the biomedical or sociocultural perspective. While the biomedical explanation results in the identification of disease by means of scientific proof (germ theory), the sociocultural explanation relates to the resulting personal experience, namely illness (Chrisman 1991a:47). The sociocultural explanation entails the equilibrium, supernatural and witchcraft explanations (Chrisman 1991a:49-50). Transcultural nursing bridges the gap between the biomedical and sociocultural perspectives, resulting in culturally congruent care as opposed to a medical ethnocentric approach (Chrisman 1991 a: 47-48; Germain 1992: 7 \& 9). In consequence, the biomedical and sociocultural perspectives regarding sickness should be well understood by student nurses.

\section{Sickness behaviour}

Sickness behaviour is man's evaluation of his health status and his consequent actions (Akinsola 1983:21-23). It is included in the curriculum according to two categories namely, pathways to health and treatment strategies (Akinsola 1983:23; Chrisman 1991a:51).

\section{Pathways to health}

Pathways to health are classified into the professional health care system as represented by the western medical channels and the sociocultural (generic) system. The latter include traditional healers, home care and self-modication (Akinsola 1983:23). Students have to develop insight into their own position in relation to the professional and sociocultural systems.

\section{Treatment strategies}

Apart from biomedical treatment strategies, students should also gain knowledge about sociocultural strategies which also include natural remedies, magic-religious remedies and altemate physical interventions (Spector 1991:29; Chrisman 1991a:51). Natural remedies include herbs, animal products, rest and diet and the advantages and dangers of these remedies should be understood by students. Magic-religious remedies include wearing of talismans, prayers and other rituals to ensure good luck or to prevent bad luck by pleasing the gods.

Alternative physical interventions include traditional surgical procedures or procedures such as massage. Students should leam to promote the continuation of harmless practices, while protecting the patient from harmful ones. An example of this might be to discourage the simultaneous ingestion of pharmaceutical and traditional medicines, while encouraging relaxing techniques such as meditation. Germain (1992:2) accentuates the reassuring effect of the continuation of traditional practices by patients in the biomedical health care system.

\section{THE TRANSCULTURAL NURSING PERSPECTIVE}

The relationship between culture and health according to the transcultural nursing perspective, can be included at strategic points in the curriculum to ensure correlation with relevant traditional nursing content. According to Leininger (1978:474-477), a thorough comparative study of at least two cultures is more appropriate than a superficial overview of various cultures. The main cultures served by the nursing school could be selected for such a study (Germain 1992:8). Leininger's seven cultural and social structure dimensions, supplemented with world view and communication, serve as a framework for the inclusion of this content in the curriculum.

\section{World view}

World view represents the frame of reference by which man interprets the world and influences his actions, behaviour, aims and perceptions (George 1990:335). Two contrasting world views are for instance, the supernatural and mechanistic perspectives. The supernatural perspective encompasses thought processes and a resultant fatalistic approach to life which may limit the effect of health education due to suppression of personal accountability. The mechanistic perspective is a rational approach that considers causal relationships and leads to the biomedical explanation of health and disease as well as preference for scientifically proven medical treatment (Chrisman 1986:59; Malan 1988:61). Comparison of the world view of the selected cultures therefore will lead to understanding of similarities and differences concerning perspectives on health, disease and sickness behaviour.

\section{Religion}

Religion, like world view, provides a frame of reference for both looking at the world and health and disease (Spector 1991:53). These phenomena can be explained from a magic-religious perspective. There is a very fine distinction between magic and religion. According to the former perspective, man is dependent on personalized supernatural beings such as gods or spirits by means of invocation. The latter involves non personalised forces and manipulation thereof by man (SKA 100V, Enigste studiegids 1991:287-288). Religion provides meaning to life, death, health and disease (Luna 1989:23) and man aims to maintain or restore equilibrium with the spiritual world by means of rituals such as prayer, offerings to the gods and manipulation of magical forces (Malan 1989:42).

\section{Cultural values and ways of living}

A comparative study of cultural values includes the following
- Perception of man as inherently good or bad.

- The nature of human relations namely:

- Whether people are regarded as equal or altematively, positioned in a hierarchal manner.

- Whether emphasis is placed on the individual or the group.

This understanding provides insight into needs and practices concerning consultation and decision making.

- The relationship between man and nature ie whether man and nature is an integrated whole, or whether one controls the other. When people believe that man controls nature, faith in medical science is strong. People who regard nature in control, are often fatalistic (Giger \& Davidhizar 1990:202).

- Orientation towards time, ie whether people focus on the past, present or future. Future orientated persons will be more susceptible to precautions insuring future good health, while persons who focus on the present are more concerned with immediate needs. Perception and understanding of time is included becauce this is important when nurses explain schedules to patients (Giger \& Davidhizar 1990:201-202).

Cultural ways of living include coping with life processes, pain and psychological distress, basic human needs, and norms that have a direct influence on nursing care.

Examples of life processes that could be included in the comparative study are contraception and conception, pregnancy and labour, child rearing practices, adolescence and ageing.

Culture determines the ways man copes with pain and psychological distress (LudwigBeymer 1989:283-297). Knowledge of the various coping mechanisms and the nurse's own perspective, will reduce ethnocentrism by the nurse in this regard. According to research, nurses make conclusions about patients' experience of pain and psychological distress from a personal cultural perspective leading to stereotyping of patients from cultures with which the nurse is unfamiliar (Davit, Davitz \& Higuchi 1977:558)

Meeting basic needs within the cultural context can also be included in the comparative study. Andrews (1989:148-149) describes measures specifically to care for the hair of a black person and Leininger (1988b:18-23) discusses the cultural significance of food

Cultural norms such as personal space and chastity have a direct influence on nursing care 


\begin{tabular}{|c|c|c|c|}
\hline $\begin{array}{l}\text { BASIC EOCIOCULTUAAL } \\
\text { ANTHAOPOLOOY }\end{array}$ & TRANGCULTURAL NUASING & BELFKNOWLDCE & CULTURAL ISSUES \\
\hline Cuture and related concepts & $\begin{array}{l}\text { Leininger's nursing theory: overview } \\
\text { Position of nurses in relation to the } \\
\text { biomedical and sociocultural health }\end{array}$ & $\begin{array}{l}\text { Sterecoypes about cultures that } \\
\text { ditie trom that of studients } \\
\text { Ethnocentriem }\end{array}$ & $\begin{array}{l}\text { Efiect of ethnocentriem on the } \\
\text { therepeutic reletionahip }\end{array}$ \\
\hline $\begin{array}{l}\text { Workdview and Leininger's eoven } \\
\text { cultural and social structure } \\
\text { dimenaiome a culturel syeteme }\end{array}$ & $\begin{array}{l}\text { Comparative study of at } \\
\text { bat two cultares by mears } \\
\text { of the coven culturd and eocial } \\
\text { structure dimenaione, worldview } \\
\text { and communication }\end{array}$ & $\begin{array}{l}\text { Charecterietice of students' onn } \\
\text { cultures }\end{array}$ & $\begin{array}{l}\text { Reapect tor cultural diversities } \\
\text { and univeneditios }\end{array}$ \\
\hline 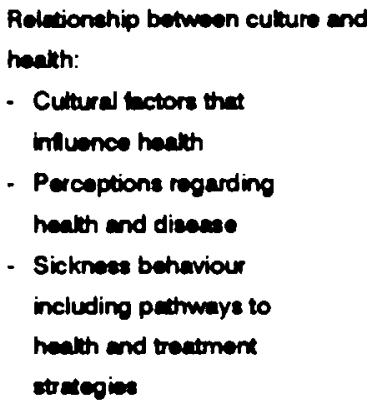 & $\begin{array}{l}\text { The nureing process: a treneculurd } \\
\text { nureing approach }\end{array}$ & 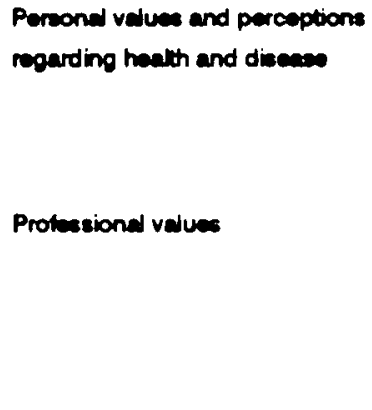 & $\begin{array}{l}\text { Imposition of the biomedical } \\
\text { model on patients }\end{array}$ \\
\hline
\end{tabular}

Figure 1: Transcultural concepts within the basic nursing curriculum

and should be explored. Insight into personal space norms enables the student to maintain a therapeutic relationship without intruding the space reserved for intimate contact. Interventions such as the physical examination and catheterization could be in direct conflict with the norm of chastity (Morse \& English 1986:72; Giger \& Davidhizar 1990:199-200).

\section{Kinship and social factors}

Kinship is culturally universal but its nature and relations within the kinship system concerning health and illness, differ between cultures. Kinship as a support system or as power relations influencing decision making need to be explored.

\section{Kinshlp as a support system}

The kinship system is mostly responsible for support and protection and is utilized by the nurse. It is important that nurses understand the culturally prescribed role of family members, for example in some cultures a female relation rather than the husband, supports a woman during labour (Burrows 1983:479).

\section{Power relations and decision making}

Knowledge about power relations and decision making procedures is important as consultations and decision making often are required in the health care system. Factors that influence this process are the distribution of authority and decision making responsibilities in the kinship group and in many developing societies, elderly family members play a key role in decision making (Anderson 1987:11); the patient does not necessarily carry the responsibility for decision making in his health care situation. The relative importance of the individual versus the group determines whose interests will be protected during decision making. In societies with an ancestor cult, consultation might stretch as far back as the ancestors.

\section{Political and legal factor}

According to Adlem (1993:14) the nurse must understand the political environment in which health care is rendered. It is especially important for promoting community mvolvement and acceptance of health care delivery by the community. This comparative study could include political demands, identity of community leaders through which involvement can be negotiated and the extent of community involvement sought by members of the target group (Leininger 1991b:253; Adlem 1993:18; Crisp 1993:8). Akinsola's (1983:48-49) classification of political authority- traditional, charismatic and legal or a combination-provides a framework for the identification of community leaders. Visiting of the sick as a political function is also an important issue that can be included. Insight into the latter will lead to a more flexible approach on the part of the nurse and could reduce conflict between the nurse and the community regarding for instance. visiting hours and number of visitors allowed in hospitals.

\section{Economic factors}

The economic realities, living conditions and resultant social problems that influence health, should be compared. Knowledge of the main economic activities provides insight into health needs associated with the level of industrial development and specific occupational health problems. (Akinsola 1983:20-21; Leininger 1978:452). Industrialized rocieties require occupational health services and pre-industrialized societies regard basic services which contribute to socio-oconomic upliftment, as a priority (TPA Focus Area Curriculum 1993:4-5).

\section{Technological factors}

The level of technological advancement influences the technological level of health care required. In a country like South Africa health care noeds range from technologically advanced to basic care (IPA Focus area Curriculum 1993:7). Advanced health services such as haemodialysis and neurosurgery, will be concidered as irrelevant by developing communities, whilst being demanded by developed communities (Ntosene 1993:36).

\section{Educational factors}

There is a correlation between attitudes towards health and health related factors (such as planned parenthood) and the educationa! level of a community; education influences the extent to which patients will accept ideas that 
do not conform to traditional views (Akinsola 1983:20-21).

\section{Communication}

A comparative study concerning communication within selected cultures includes communication patterns, language, language problems and communication etiquette in the health care situation. There are cultural differences regarding communication etiquette such as a required introductory conversation about general matters, admissibility of direct questions about personal matters and implications of non-verbal behaviour. Simple words such as "yes" can mean "I heard you" or "I understand." (Anderson 1987:12; Giger \& Davidhizar 1990:199-200). It is essential that nurses are aware of different meanings and interpretations in a multicultural situation.

\section{SELF-KNOWLEDGE}

This knowledge entails insight into individual personal and professional perspectives and their effect on the nursing care situation (Chrisman 1991b:37). Self-knowledge is a prerequisite for the ability to render culturally congruent care. Students should be given the opportunity to compare their personal beliefs and practices and discuss the possible effects of these on patient care (Capers 1992:23; Gagnon 1983:129).

\section{Personal values}

Research by Elliot (Malan 1989:42) suggested that education based on the Westem model does not result necessarily in a changed world view in that two-thirds of medical students at the Medical University of Southem Africa retained their spiritualistic cosmology; they believed in the existence of supernatural forces that should be reckoned with. Personal values should therefore be explored. Poggenpoel (1993:39) believes that nurses who are comfortable with their own world views will be able to accept and respect other persons' world views. Spector (1991:3-14) discusses suitable themes such as perceptions of health and disease, and traditional remedies used by the student herself at home would be appropriate aspects of behaviour to explore

\section{Professional culture}

Professional orientations of nurses might differ from that of the patient and discussions in this regard aim to prevent medical ethnocentrism in the nursing care situation. An example of such puzzling professional practice might be to cover a child with pyrexia lightly if at all, while the mother requests more blankets to prevent the child from "catching a cold" (Anderson 1987:8)

\section{CULTURAL ISSUES}

Cultural issues are those issues that should be debated by students to promote moral development. Students must learn to respect that which is important to the patient (Boyle \& Andrews 1989:359) and Leininger (1991a:14) emphasises that we have to rise above cultural conflict and racism. Many topics can be debated and only a few examples are provided:-

- Imposition of biomedical treatment strategies on the patient.

- The effect of bureaucratic rules such as restrictive visiting hours on cultural prescriptions regarding care of the sick by the kinship system. In some cultures patients seek support from members of the kinship system rather than the nurse.

- Human rights within the cultural context.

(Leininger 1991a:13; Spector 1991:59-61; Anderson 1987:11).

\section{CONCLUSION}

The transcultural nursing component of the curriculum is preceded by a basic sociocultural anthropology course. Transcultural nursing content includes a comparative study of at least two cultures, development of self-knowledge and debating cultural issues and it is not appropriate to teach students lists of cultural characteristics. Figure 1 represents a summary of the inclusion of this subject content in the curriculum

\section{REFERENCES}

Adlem, W.L.J. (1993). Matro persoptuele maluenng wan gesondhends cangebenthede mel besondere wenysang no weplesgondenug. Ongepubliseerd UNISA

Akinesle, HY. (1983). Behomoural ecience for murses London: Churchill Livingstonc

Anderson, J.M. (1987) The cultural contexd of carng Canatian Critical Care Nursing Jowmal, 4, 4, 713.

Andrews. M.M. (1989). Culture and nutrition. In Transecultural concepts in mursing core, edited by J.S. Boyle and MM. Andrews. Philedelphic Lippincolt. 1989. 333363

Boyle, J.S. \& Andrews, M.S. (1989) Transcultural concepes in nursing care Phuladelphie Lippuncod

Burrows, A. (1983). Patient centered nursung care m a mult racial society the relevance of ethnographic perspectives in nursing curnicule Joumal of Adranced Nurnieg. (8), 477485

Capers, C.F. (1992) Teaching cultural content a nursing imperative Holustic Nurse Pracece, 6, 3, 1928

Chriaman, N.J. (1986) Transcultural care In Masby's comprehenerve rmine of entrcal care; ediled by D Zschoche. St.Loul Mosby, 1986, 3869

Chriaman. N.J. (19910) Culaural aysiems in Conoer nursin: a compreherserve laxtboat. odited by $S$. Bard R McCorkle and M Grant, Philedelphis W.B Sounders, 1991.4554

Chrtaman. N.J. (1991b) Culture sensuuve nursung care In Mectical surgical mursing: parhophysologic comcopts. odited by M.L Punck S.L Woods, R.F Croven J.S Rokosky and $P M$ Bruno, Second edition. Philadelphis Lippincota, 1991, 3447

Crisp. N. (1993) Commumn imohemens Unpubleshed report to the Function l Menagement Commene of the Depertment of Health 03 May 1993

Devtex, LL \& Derks, J.R. \& Hipectu, Y. (1977) Crom cultural inferences of physical pain and poychological distres. Nursing Times, April 14, 521558.

Dobsen, S.M. (1983). Bringing culture info care. Nursing Times, 79, 6, 53 \& 5657 .

Gagnon, A.J. (1983) Tranecultural nursing: including it in the curriculum. Nursing and Health Cars, Murch 1983. 127131

Georze, J.R. (Editor). (1990). Nursing theorias The base for professional mursing practice. Third edition. Englewood Cliffs: Prentuce Hall.

Germata, C.P. (1992) Cultural care: a bridge between sickneas, illness and disene. Holistic Nurae Practice. 6.3.19

Gizer, J.N. Davldwzar, R. (1990) Transcultural nursing assesement: method for edvencing nursing practice. Internationd Nursing Review, 37, 1, 199202.

Herbere, P. (1989). Theoretical foundations of transcultural nurung In. Tranecultural comaspts in mursing care, adited by J.S. Boyle and MM Andrews. Philadelphis: Lippincoth, 1989, 359.

Letalneer, MM. (1978) Tranecularal mursing concopto. theories and proctices. New York: Wiley.

Leininger, MM. (1988b) Transcultural cating pattems and nutrition tranacultural nursing and enthropological perspectives. Holistic Nursing Practiox, 3, 1, 1625

Leininger, M.M (19918). Celebration of mursing: a transcultural human care ethos with elhical considerasions Keynote centennial eddres for one hundted years of nursung in South Africe. Unpubliahed UNISA.

Leininger, MM (19916). (Editor). Culture Care Diwersity and Univeraling: atheary of nursing. New York: NLN

Ludwis Beymer, P. (1989). Transcul tural eppects of pain In: Travsaltural comcopts in nursing cane, odited by J.S Boyle and M.M. Andrews. Philadelphia Lippincotr. 1989, 282302.

Lana, LJ. (1989) Trancultural nursing care of Arab Mualims Joumd of Tronscultural Nursing 1, 1,22 26

Melen. J.S. (1988) The cosmolozical fector in development programmes. Suld Afnkaanse Tydabrifvir Emalogie, 11, 2,61 66

Malen, J.S. (1989). Ontwikkelingsperspektief vanut kogniliewe antropologie Suid Afnikanse Tydetrif vir Emologie, 12, 2,3949

Morne, J.M Englich. J. (1986) The uncorparation of cultural concepts unto basic nursing texks Nursing Pepers. Perspectives on Nurring, 18, 2,6976

Nteane, C. (1993) The challenge of prumary health care Nursing RSA, 8, 10, 3543

Pervan, V \& Bryce, L \& Wermer, I.D (1989) CA cesophagus: Bewitched of bewildered? Nurnis RSA, 4. 6, 16-19.

Poessenpoed, M. (1993) The future of poychiate nursing Nursing RSA, 8, 8, 3942

SKA 100 V, Engste Studregids, (1991). Unversiteat van Suid Afriks, Depanement Antropologie en inhoonse Reg Sosio kulturele Aniropologie: Enigate Studiegids vir SKA 100 V. Pretona, 1991

Spector, R.E. (1991) Cultural drernty in hedth and illness Norwalk Appleton Lange

Transvase Previnalale Admialstrasle (TPA). Stralegiese Beplarning vir en die Herposisionerung van Verpleegonderwys in die Transval Fokusurea Kurrikulum Verslas rakende vordering en ennbevelings Ongepubliseerd Ann Latsky Verplegingakol lege, 1993

\section{L de Villiers M.A. CUR (UNISA)} Senior tutor

ANN LATSKY NURSING COLLEGE

D van der Wal M.A CUR (UNISA) Lecturer

Department of Nursing Science, UNISA 